Health, hygiene and biosecurity: Tribal knowledge claims in the UK poultry industry

Brigitte Nerlich, Brian Brown, Paul Crawford 
Health, hygiene and biosecurity: Conflicting knowledge claims in the UK poultry industry

\begin{abstract}
Since 1997 the world has been facing the threat of a human flu pandemic that may be caused by an avian virus, and the poultry industry around the globe has been grappling with the highly pathogenic strain of avian influenza, or bird flu in more informal terms, H5N1. The UK poultry industry has lived with and through this threat and its consequences since 2005 . This study investigates knowledge claims about health, hygiene and biosecurity as tools to ward off the threat from this virus. It takes a semi-ethnographic and discourse analytic approach to analyse a small corpus of semi-structured interviews carried out in the wake of one of the most publicised outbreaks of H5N1 in Suffolk in 2007. It reveals that claims about what best to do to protect flocks against the risk of disease are divided along lines imposed on the one hand by the structure of the industry and on the other by more 'tribal' lines drawn by knowledge and belief systems about purity and dirt, health and hygiene.
\end{abstract}




\section{Health, hygiene and biosecurity: Conflicting knowledge claims in the UK poultry industry}

\section{Introduction}

Present day concerns about avian influenza or 'bird flu' in more informal terms began with a 1997 outbreak in Hong Kong which resulted in six fatalities among the 18 people affected (Cauthen et al., 2000; Tumpey et al., 2002; Fleming, 2005). This was quickly identified as a new, highly pathogenic strain of avian flu, named H5N1, which originated in chickens (Lin et al. 2000; Cyranoski 2001). Chicken exports were banned, about 1.6 million chickens were slaughtered and the virus seemed to have been eradicated. It re-emerged in 2003 in East-Asia at the same time that a strain of low pathogenicity, H7N3, infected poultry in the Netherlands (see Elbers, et al., 2004), devastated the poultry industry there and killed one veterinarian. Since then bird flu has claimed the lives of 235 people (World Health Organisation, 2008). Governments and health protection agencies have also been on high alert, in line with the World Health Organisation's (2006) action plans and its warning that avian flu strains may cause a global human flu pandemic, similar to the one that killed millions of people in 1918 (see Barry, 2004). Now the world faces a double risk: the appearance of further new animal diseases and a small but as yet undisclosed risk of a human health catastrophe.

Between 2005 and 2008 there have been several UK avian flu 'scares' (Nerlich \& Halliday, 2007; Nerlich et al, in press). Most notably, there was an outbreak of H7N3 on a poultry farm in Dereham, Norfolk in April 2006; an outbreak of highly pathogenic H5N1 was confirmed in poultry in Upper Holton, Suffolk, in February 2007; and another such outbreak was confirmed in poultry in East Anglia in November 2007).

Whilst media coverage has been studied (Nerlich \& Halliday, 2007), less attention has been paid to poultry farmers' own conceptualisations of disease risk and measures to reduce it. In this context it is valuable to explore not only how 
they understand the measures taken to reduce risk but also how a widely dispersed group of people such as farmers and infection control specialists come to share understandings of how to undertake this common core of risk management procedures. Whilst Government policies play a role in this coordination of action (DEFRA, 2005; 2006a; 2007) the social implementation and collective meaning of infection control measures is less fully understood. It is therefore to cultural anthropology that we turn in making sense of avian flu precautions as a social phenomenon involving collectively co-ordinated thinking and practice. In exploring the research approach to these phenomena, in Argonauts of the Western Pacific, Bronislaw Malinowski wrote:

...the goal of ethnographic field-work must be approached through three avenues:

1. The organisation of the tribe, and the anatomy of its culture must be recorded in firm clear outline. [...]

2. Within this frame, the imponderabilia of actual life, and the type of behaviour have to be filled in. [...]

3. A collection of ethnographic statements, characteristic narratives, typical utterances, items of folk-lore and magical formulae has to be given as a corpus inscriptionum, as documents of native mentality.

These three lines of approach lead to the final goal, of which an Ethnographer should never lose sight. This goal is, briefly, to grasp the native's point of view, his relation to life, to realise his vision of his world. (1922: 24-25)

Poultry farmers are not a 'tribe' in Malinowski's sense of being bound by ties of locality and kinship. Recent theorisations of the idea of the tribe however have emphasised how contemporary social collectives may be geographically diverse and linked by electronic and print media rather than familial relationships. According to Maffesoli (1996:98), the contemporary tribe is 'without the rigidity of the forms of organization with which we are familiar, it refers more to a certain 
ambience, a state of mind, and is preferably to be expressed through . . . appearance and form'. The form of sociality proposed by Maffesoli $(1991 ; 1996)$ is one where people form social bonds and associations of many diverse types in contemporary society. Rather than being determined largely by government policy, duty or contract, members of these 'neo-tribes' may be motivated by aesthetic considerations and affectional bonds. These 'networks of solidarity' aim towards a re-enchantment of the world (Maffesoli, 1996: 72).

Thus, Maffesoli's work, which is becoming increasingly influential in the study of cultural life, subcultures and communities forms a valuable means of understanding the diverse, distributed yet curiously co-ordinated activities of groups and individuals in the farming industry as they cope with agricultural, governmental and pathogenic challenges. Following Malinowski's advice, we will first try to provide an overview of the 'organisation of the tribe', or, in this case the organisation of the poultry industry. We shall then discuss how the participants in our research reflected upon the 'imponderabilia of actual life', in particular the uncertainties surrounding infection and infection control, biosecurity, cleanliness and hygiene and the risk of disease outbreaks and the rituals employed to moderate these hazards. It should be stressed that we use the concept of the 'tribe' as a heuristic model, indeed one may say, following Geertz, a 'fiction', that allowed us to make sense of data collected during interviews and to extract meaning from the texts we collected. As Geertz maintained;

[...] anthropological writings are themselves interpretations, and second and third order ones to boot. (By definition, only a 'native' makes first order ones: it's his culture.). They are thus, fictions; fictions in the sense that they are 'something made', 'something fashioned' - the original meaning of 
fiction - not that they are false, unfactual, or merely 'as if thought experiments' (Geertz 1973: 15; see also Subba and Som, 2005)

In this paper we will report on a study of the structure of the 'tribe' and its enactment of biosecurity 'rituals'. It is based on a qualitative analysis of a corpus of semi-structured interviews we collected, what Malinowski called the 'corpus inscriptionum'. In addition we will use some background material regarding both the industry structure and the biosecurity advice it issues to its members and receives from policy makers. Unfortunately, as DEFRA (2006c) reports on its website 'a clear understanding of the poultry industry, including movements and interactions between the various parts is currently not available. Therefore, there is uncertainty about the potential for infectious diseases to spread through the poultry industry in Great Britain'. It is therefore all the more important to see what our participants might have to say about their 'organisation' and how they construct themselves as a (tribal) 'community' or a range of 'communities'.

\section{Conceptual background}

As the Chicago sociologist Julius Roth (1957) pointed out about half a century ago, uncertainty and ritualisation seem to go hand in hand when coping with contagious diseases, especially when the routes of transmission are unknown or uncertain.

These uncertainties leave the way open for ritualized procedures that often depend more on convenience and ease of administration than on rationally deduced probabilities. They also leave the way open for irrational practices that can properly be called "magic." (Roth 1957: 310)

This ties in with Malinowski's (1922, see Senft, 1997) functional views of ritual actions, where, 'ritual enables man to deal with his fear of the unknown, to fence off the terrifying and unendurable' (Zuesse, 1974: 486). Rituals provide ways of 
superimposing systematic actions upon what is as yet unsystematic and uncertain. As Mary Douglas (1966, 1992), coming from a different but complementary anthropological direction, has shown, one way of doing this is by demarcating, ordering, separating what is inherently untidy and thus to impose a system. This activity implies, for example, making differences between what is 'in' and what is 'out' and what is 'clean' and what is 'dirty'. As we shall see in the following, the poultry industry, our hypothetical tribe, fractures into two, partly overlapping, tribes who disagree where lines should be drawn between what is in and out and between what is clean and what is dirty. They also vary in their beliefs regarding the effectiveness, magical force or power of the ritual they all share, namely imposing biosecurity measures. For Maffesoli $(1991 ; 1996)$ on the other hand, ritual is much more concerned with appearance and surface, offering perhaps a communicative function. In his view, the rituals of everyday life are also somewhat conservative, offering a bastion against the attempts of more powerful agencies to impose their vision of progress (Sheringham, 2006).

The activities of poultry farmers are overseen by a variety of agencies in addition to the government itself. These offer interventions and advice on issues from animal welfare to biosecurity. The main organisations in this respect are the British Poultry Council, the British Egg Industry Council and the National Farmers' Union. Many of these interventions and guidelines are themselves responses to public concern. After a series of food scares, especially regarding salmonella in the 1980 s, the industry has introduced various schemes to boost consumer confidence and regulate food safety. The most well-known schemes are the Lion Code for eggs, the Red Tractor code for meat, linked to the Assured Chicken Production or ACP scheme. More recently, the industry has also got involved in other schemes related to food safety, such as the Integrated Pollution Prevention and Control regulations or IPPC scheme and the Hazard Analysis Critical Control Point or HACCP scheme. The role these play in the lives of those connected with 
the industry was attested by the fact that all were mentioned by our participants, especially by owners of integrated poultry farms and poultry disease and food safety experts. We can, of course, not say how far each of these schemes was just seen as a 'tick box' exercise or not.

The major division in poultry farming is between factory farming and free range farming. This is a divide that structures not only the industry itself but also discourses about the origin, spread and prevention of various poultry diseases, most importantly avian influenza. It is, as we shall see, a major force of 'tribalisation' encouraging a strong sense of subdivision in the industry. This intersects with the social complications related to a variety of diseases to which poultry can succumb. These range from amyloidosis to yolk sac infection or omphallitis (http://www.thepoultrysite.com/diseaseinfo/). Avian influenza or bird flu is a zoonotic disease that can spread between poultry and humans through direct contact with faeces or blood and can cause death in both species. Of specific concern is the possibility of the avian influenza virus transmuting into a virus that could be transmitted between humans, causing a world-wide pandemic of human influenza (Donaldson, 2005).

\section{Corpus and methods}

In order to gain access to their knowledge and understanding of disease risks and the role of biosecurity measures in disease prevention, fourteen semi-structured interviews with poultry farmers and members of affiliated fields, such as food safety experts and vets were carried out in 2007. Poultry farm visits and tours were undertaken which facilitated the collection of field notes.

Our corpus is relatively small and does not cover all aspects of the industry. This reflects, in part, difficulties of access, as there were various outbreaks of avian 
influenza while we were in the process of recruiting. Participants were interviewed between April and October 2007. We only interviewed chicken farmers, and excluded turkey, duck, goose or quail farmers. Farmers in our sample had farms of various sizes, from integrated farms to small-holdings. Animal health experts were interviewed for their insights on biosecurity and disease issues. Most of the interviews with farmers were carried out in East Anglia, as this region has a high density of poultry farms, and is so far the region with the highest incidence of avian flu in poultry flocks. The interviewees' details are summarised in table 1.

\section{Insert table 1 about here}

Whereas the industry is at its densest in the East and West of Great Britain and most bird flu outbreaks happened in the East, outbreaks of bird flu in wild birds have so far only been reported in the North (Scotland, one swan April 2006) and the South (Dorset, six swans, one Canada goose, January/February, 2008), although the risk of the virus 'entering' Britain was always believed to be via wild birds and East Anglia was believed to be the 'front line'.

We used a qualitative approach for our study since this is acutely sensitive to the context in which knowledge is enacted about the poultry industry and participants individually and collectively cope with disease threats (Bryman, 2004; 2006). Interviews were semi-structured, focusing upon questions in the following areas: the nature of interviewees' business or knowledge of the poultry business; the main challenges faced by the poultry sector and poultry food industry; interviewees' understanding of biosecurity, hygiene and cleanliness. Interviews lasted between one and one and half hours and all interviews were fully anonymised and transcribed. 
We undertook an iterative analysis process, rereading and coding transcripts, notes and documents, generating themes, and cross-checking these through discussions between authors. Thematically related parts of the embedded analysis in each data source were grouped together. The authors discussed the coding of transcripts with each other, ensuring inter-researcher reliability of interpretation and enhancing analysis. Two core themes were systematically identified and subthemes defined within these core themes.

- Core theme 1: The structure of the 'tribe' - consensus and divisions regarding disease risks

- Core theme 2: Biosecurity - magic or fallacy?

It should be stressed however that the way informants spoke about these themes varied substantially, that is to say, the themes were distributed unevenly over the interviews. One person might for example speak at great length about the poultry industry as such, another about the issue of biosecurity or risk. This depended in part on the professional background of the informant, whether they were for example a food safety expert (who then used the term risk assessment quite frequently, for example) or an owner of a large poultry farm who would talk more about biosecurity challenges, especially at a time of heightened disease threat. ${ }^{1}$

\footnotetext{
${ }^{1}$ This qualitative study complements, to a certain extent, a quantitative study undertaken by Italian researchers (Abbate et al., 2005) who asked poultry workers about knowledge, attitudes, and practices regarding avian influenza. They found that avian influenza was seen as a low occupational hazard and that knowledge about transmission and prevention measures could be improved. Our study, by contrast, did not set out to measure knowledge but to get more indepth insights into how knowledge around biosecurity is constructed in various contextual settings and by a variety of stakeholders. For information about lay knowledge about avian influenza in Europe, see Mossilialis and Rudisill (2008).
} 


\section{Results and Discussion}

The first part of the analysis will therefore focus on how various members of the 'poultry tribe' describe and structure each other in relation to disease, a structuring that on the one hand involves the apportioning of blame, but also focused on how the rituals of biosecurity are enacted and how beliefs about the magical power of cleansing and hygiene are contested.

\section{Core theme 1: The structure of the 'tribe' - consensus and divisions regarding disease risks}

Participants agreed that the industry they are involved in is a 'a huge industry' (\#6), 'a wide flung industry' (\#7) and an industry characterised by competition, with consolidation on the one hand and expansion on the other, an expansion, especially in the free range sector, that was however sometimes hampered by lack of land: 'it's another factor that inhibits the growth, the physical growth of free range, or the free range, free range industry in this country is the variable space for growing the new birds' (\#1).

The industry is perceived to be under pressure from consumers and animal welfare campaigners, such that smaller poultry 'units' are emerging:

[...] and then of course you've got your small people who are steadily expanding, but the small flocks, the tiny flocks, and they keep expanding those and that's, they are the recruits to the industry. And the existing cage people realise that the game is up in a way, you see by 2012 cages, conventional cages are banned anyway. [...] There may be other opportunities for them but generally they wouldn't seek to become free range producers because they probably haven't got the land. They'd have 
been used to a much larger flock, say 30,000 birds on a 3 acre concrete farm. (\#1)

The risk of bird flu to the industry is not directly discussed with regard to these tendencies, but indirectly dissent emerged between two sectors of the industry about the causes and spread of the avian influenza virus, as well as the status of biosecurity and hygiene. One can here observe a factionalising form of 'tribalisation' (Bauman, 1992; Maffesoli, 1996) based on diverging beliefs about health risk, profit, animal welfare and human health. As Bauman has noted about tribal affiliations and divisions based on belief, under conditions of uncertainty, participants have no other grounds but the individual decisions to identify with' (Bauman, 1992: 697).

Some participants highlighted the risks posed by bird flu to 'the industry' as such. They stressed that it was unlikely that humans would be affected, but what was at stake was the 'survival' of the industry, not the birds.

So going back to avian flu I mean it's still a potential risk, as I say the risk is probably much greater to the survival of the poultry industry, it's not going to cause any major problems with consumers. (\#6)

Yet the factionalised, tribalized enclaves of belief mentioned earlier meant that fortunately for 'the industry', consumers in Great Britain were perceived to be unperturbed by the risks of 'bird flu'.

I think as a nation we've actually got a bit blasé about food scares so with avian influenza this H5N1 when it first sort of kicked off and there had been cases in Europe or whatever, when there was a new case in western European the Italian consumption just dropped the way off, I think the Italian consumers were petrified whereas the Brits thought well yeah you might get avian influenza but we still want to barbeque something and it hasn't affected the industry too much. (\#8) 
On the whole, participants had confidence in 'the industry' being able to deal with disease threats. They were especially proud of various 'assurance' schemes that had been introduced after the salmonella food scare in the 1980 s, such as the Lion Mark scheme introduced in 1989: 'The UK industry has put a huge emphasis on reduction of salmonella and it is doing pretty well, it's doing pretty well' (\#9).

However, whereas the egg industry was proud of having won a victory over salmonella, the threat of bird flu was recognised as a different, yet contested issue. Disagreement emerged between speculations about the origins of avian flu in terms of disease vectors. One form of division was the distinction between wild birds or 'the industry' as possible sources of infection. Free range birds, who are exposed to wild birds, were seen by some as posing a threat to the rest of the industry. On the other hand some saw industrialised farming, especially in the Far East as the real origin of the current outbreaks of bird flu all around the world.

The split seemed to follow lines of tribal subdivision between 'factory' farmers and 'free range' and organic farmers. The impetus here came from contesting whether it is better to keep birds 'in' or 'out' and whether to keep them clinically clean or exposed to some dirt and bacteria.

One participant, associated with organic food production, pointed out that, on the one hand, 'the government and the industry was trying to say that $[\ldots]$ the weakness in the system was probably outdoor birds' (\#10), whereas, from his point of view 'the industry is creating susceptibility [to disease]' by sealing birds into hyper-clean sheds, preventing them from going 'outdoors' and so to strengthen their immune system by exposure to various bacteria and the reduction of stress. He went as far as to say that 'it's industrial systems which have created this new strain'. He expressed concern over the fact that priority was given to safeguarding the industry rather than public health. We shall come back to this contentious issue in the next section. 
Criticism was also voiced by more industrialised poultry producers about how best to deal with an outbreak in terms of risk communication and a plea for a type of risk communication that would not lead to 'crippling', 'wiping out', 'screwing' or 'collapsing' the industry (\#8). The issue, again, is not the health of the individual bird, but what one might call 'the health of the industry', especially the big industry. The small farmers by contrast would put more emphasis on the health of individual birds. This distinction was central to a conflict between the subdivisions of the industry, for example as expressed by a member of the opposing tribe, an organic poultry supporter, who pointed out that 'the main industry are more powerful; they can come up with a theory that it's outdoor birds that are the threat and everyone believes it and will act on it and even we were worried, we half believed it' (\#10). This remark was made with reference to an outbreak of bird flu in East Anglia, which later turned out not to have been caused by wild birds, something that everybody had expected, but rather by breaches in biosecurity at an industrialised poultry 'plant' (see Nerlich et al, in press).

There is therefore a rather sharp, tribalised divide between free range and organic poultry farmers and factory farmers. Factory farmers blame free range and organic farmers for increasing the risk of bird flu, as their birds are exposed to wild birds and therefore to 'dirt' in the form of bird droppings and disease. Free range and organic farmers blame factory farmers for increasing the risk of bird flu by not exposing their birds to natural pathogens and by also exposing them to more stress, thereby depleting their immune system and making them more susceptible to disease.

One organic poultry supporter pointed out an inherent risk associated with making the industry the focus of protection and the focus of targeted risk 
communication instead of the birds, as this might lead to the wrong disease management strategies being implemented: 'there's a lot of pressure now with bird flu to intensify the whole industry around the world, to, to stop outdoor flocks and industralise and they've probably got it totally wrong, that's probably that's causing the bird flu'. This view was endorsed by a manager of a nature reserve who said that 'there is no proven case worldwide of a wild bird bringing bird flu into $[\ldots]$ into any of the countries, it's all through the poultry industry [...] it's the poultry industry that is to blame and it's been proven time after time after time that you know bad management in that industry has resulted in the spread of the flu' (\#12). The observed tribalisation based on disputes about disease and 'dirt' is reinforced by mutual blame for outbreaks of disease. In the next section we will focus on the various types of enactment of biosecurity measures implemented to keep the disease 'out' or not letting it 'in' and the disputes surrounding their efficacy or power, whether symbolic or real.

\section{Core theme 2: Biosecurity - magic or fallacy?}

Although biosecurity became a big issue when the threat of bird flu to poultry farms became apparent after 2004, participants stressed that, traditionally, 'the poultry industry is far more geared up to biosecurity' (\#13) than other agricultural industries have been in the past, as it has had to live with wellrecognised threats from a variety of infections, such as Newcastle disease. As one participant told us: 'you know there used to be a joke wasn't there that the cattle farmers had heard about biosecurity, the sheep farmers hadn't heard about it and the pig farmer thought it was having a toilet brush' (\#13).

Bird flu has been around for a long time in one form or another. H7N3 almost wiped out the Dutch poultry industry in 2003 and even the 'new', potentially pandemic strain, H5N1, hit a poultry farm in East Anglia in 1992, ironically owned by Bernard Matthews, the owner of the farm hit again by the virus in 2007 . But 
these are only two examples of many outbreaks of avian influenza world-wide (see Alexander, 2000). The recent outbreaks caused by H5N1 are perhaps more worrying than past ones, as the virus has been transmitted from animals to humans and caused over two hundred deaths world wide (see Sanco, 2009), and as there is a chance of the virus mutating so as to become transmissible between humans. As one expert told us:

Well the virus could mutate within the pig, in other words they could pick it up from the chicken and there can be mutations, you know the pig could then transfer that to a human. So you should never keep pigs and chicks together because that's the risk. (\#13)

Measures to prevent a human pandemic therefore include such segregation of animals on farms. However, we interviewed only farmers that specialised in poultry. Here the concerns are to prevent the virus from getting into the farms and entering the birds. Morrow (2006) defines biosecurity as 'the prevention (or control) of pathogenic microorganisms from contacting animal populations'. 'It is essentially keeping the bird separate from the bug' (ibid.) DEFRA (2005: 3) defines biosecurity as 'taking steps to ensure good hygiene practices are in place so that the risk of a disease occurring or spreading is minimised' DEFRA stresses that good biosecurity 'helps keep out exotic poultry diseases such as avian influenza and Newcastle Disease' (DEFRA, 2005: 3). So, biosecurity is all about keeping the virus 'out' or not letting it 'in', what we might call 'thresholdism'. This aligns itself with Douglas's (1966) insight that 'dirt' involves the transgressing of boundaries and Turner's (1995) focus on rites of passage as moments when ritual purifications are implemented. How one manages the threshold differs amongst the poultry tribes, that is the factory farmers and the free range farmers, as the one tribe can and does keep birds 'in' and away from the virus (although, as has been shown in recent outbreaks there are always 'holes' in biosecure defences), whereas the other cannot readily keep birds in and therefore, at least theoretically, endangers the survival of the birds owned by the other tribe and 
with it the survival of that sector of the poultry industry. In urging biosecurity measures, DEFRA (2005: 3) emphasises the communitarian benefits to 'your birds, your business, the industry and the community'.

There are therefore significant differences in how the two tribes reflect on the issue of biosecurity, the origin of the term, the usefulness and purpose of biosecurity measures and the financial implications or implementing biosecurity measures.

One large poultry farmer of organic and free range laying hens for example talked about the term 'biosecurity' in the way cattle farmers did during the foot and mouth disease crisis (Nerlich, 2004), as essentially a new concept that mapped onto old and already well-established practices: 'I mean we're always quite good with our biosecurity - do they call it now or something [...] yes I mean it's always in my mind whenever I go in and out of the huts' (\#3). When DEFRA told him to install a foot bath he said that he'd done that already anyway, that it was 'common sense' to use 'general disinfectant', 'general cleanliness' and compared this with what was going on in hospitals.

There seems to be a spectrum of biosecurity practices and beliefs about biosecurity that spread between the two extreme points of the poultry industry, between highly industrialised farms and farms that resist industrialisation, that is, between what one might call 'big biosecurity' and 'biosecurity-lite'. There also seems to be a whole spectrum of beliefs relating to biosecurity, from those believing it to be 'just common sense' to those seeing it more scientifically as a 'systems based' procedure. Both practices are based on shared biosecurity rituals, especially wheel washing and foot baths, which are seen by many as perhaps more symbolic or magic than real. 
Let us first look at what 'larger' farm owners have to say about biosecurity before describing the other end of the spectrum. We shall see that on the one end of the spectrum biosecurity is what the 'Poultry Site' describes as 'primarily a management-implemented system' (Morrow, 2006), whereas at the other end the focus is more on keeping individual birds happy and healthy.

One participant who had also witnessed the foot and mouth disease crisis (Nerlich, 2004) pointed out that 'poultry units tend to be mostly run by large companies and they're fully aware of what biosecurity is and of the costs if it's not, not properly implemented' (\#13). The system-based approach is all about rigorous 'control' of the environment in which the birds live, a type of 'control' that might be difficult to achieve for free range birds:

Well of course you have greater difficulty with biosecurity for outdoor birds because you've got exposure to feral birds, it's not a controlled environment is it? You know and it was thought that if Avian influenza came into this country, into commercial birds it could well be coming into free range. (Ibid.)

One participant who now manages an organic farm remembers what biosecurity was like when he worked on a 'breeder farm' (where poultry is raised for meat) and a 'laying farm' (where poultry is raised for the production of eggs). This extract highlights the quasi ritualistic aspects of biosecurity measures which were, as he points out, 'religiously' adhered to.

there was one of the companies I worked for and it wasn't, I mean they had their own overalls on farm, their own wellies etc but it wasn't, coming off the commercial, the breeder farms I came off we used to have our own overalls which never used to go off that farm, we had wellies for outside the buildings and inside you would go in and there was a physical barrier. I mean it was only a little one but you had to take your outside wellies off, as well as the foot dip outside to dip your feet, then you would go inside the 
door into the, what we used to call the lobby, the meal house, and then there was a physical barrier. And it was only about as big as this table but you would have then to take off your outside wellies there and get into a pair of wellies which would only ever be in that shed. And then those, those wellies were then worn in that shed and when you'd go out the shed you'd change back into your outside wellies. I mean I've been doing that for 8 10 years and then I went over the commercial laying farm, I mean they did have foot dips outside the sheds to change either every other day, well twice a week or as and when required you know so if they were mucky they'd get changed more than twice a week. But they were, they were always religiously dipped in and out the shed. You dipped them when you went in the shed, you dipped them when you came out the shed so the biosecurity was there (\#14)

Ritualistic practices, aimed at separating the inner from the outer and the clean from the dirty, were not only important to keep diseases out, but also because an outbreak would cost the commercial industrial farmer 'literally millions' (ibid.). Another participant vividly described what it meant to practice what one might call big biosecurity or industrialised biosecurity. He called it 'a spider web', where 'every possible source of hazard is looked at; so it is a massive operation' (\#6). He indicates various critical points in a chain of hazards, such as animals contaminating a feed mill or a grain trader or the farm where the trader gets the grain from. Or, with respect to chickens - what is the hatchery like, what about the parent stock, how is that farm managed and so on. This type of biosecurity approach is nowadays subsumed under the HACCP scheme, is costly and has only real benefits to 'massive' poultry operations. But even there, there are some who regard the benefits of biosecurity as not only economic but also as symbolic. One owner of a large broiler farm for example told us that as there is no vaccination against bird flu yet in the UK all depends on biosecurity: 
[...] the wheel washer so I mean that's, I do believe that to be, the supermarkets think it's wonderful, they come round on their visits, oh look at this you know. But it's cosmetic because you know with the best will in the world we've got birds flying over the hedge and defecating as they fly over the yard and this sort of thing and so the biggest fear is that we put our foot in something and walk it into our sheds. So the guys change their clothes when they get to work, so they have a set of work clothes and then we operate a double boot dipping method of keeping feet clean. Obviously hands are washed and all this sort of thing so we will have a boot, we will have a dip outside the shed, go into the control room where there will be another one and into the shed. And a lot of work has been done on this and that double boot dip combined with one scrub to make sure there's nothing in the cleats of the boots does the job.

So on the one hand biosecurity is symbolic and also quite complicated, but on the other it is 'simple' and 'basic':

It's quite simple and if you know basic hand washing whenever they come out of the shed there's the choice of alcohol or soap hand washing facilities and woe betide them if they don't do it. You can't be watching them all the time but you know for their own sake they ought to be doing it.

\section{$[\ldots]$}

You don't believe what we make visitors do if they're going into one of our sheds I don't believe there is a risk. But you know it's, again under heightened security biosecurity levels it sends out the wrong message if you let people into your sheds so we don't do it. (\#7) 
This means that implementing biosecurity measures around entrances or 'thresholds' at a big industrial poultry farm is not only effective in terms of any microbiological effect it may have, it also impresses the big supermarkets and sends out the 'right message'. It has a symbolic and, in a way, ceremonial function.

All this is quite different for smaller poultry farmers, especially if they are free range or organic. Here too biosecurity has a certain symbolic value, but a different one. This is also the case in terms of economic benefit. Keeping up strict biosecurity measures, which, again, are summarised as wheel washing and footbaths, is important because it sends out the right message to the industrialised producers that the free range farmer is doing the right thing. They know that they are regarded as being 'the weak link' in the British poultry industry (\#1) and in the disease control chain and they have to demonstrate to the 'others' that they are not a threat. Free range farmers always live in 'great fear' of 'a law suit from a big powerful neighbour saying you, it came from your unit, you're not doing enough in your biosecurity, you know your actions are irresponsible and we're going to pay barristers to prove it and we're going to turn you upside down and inside out' (ibid.). Biosecurity is there not only to keep the virus out but to keep blame at bay. Indeed, as Douglas (1992: 6) notes, the more solidarity there is in a community, the more readily will disaster be interpreted as a sign of reprehensible behaviour.

There is a huge difference then between trying to keep biosecurity up in an outdoor unit and sticking to biosecurity rules in an indoor unit. As an expert on animal production pointed out: 'the large indoor unit's okay, they're very good for biosecurity, it's like, they're like sealed units almost, no birds, no cats, no mice, no rats, no visitors, no nothing' (\#6). This approach is based on what a representative of the Soil Association called 'the fallacy of [...] biosecurity' (\#10). 
The participant pointed out that since the outbreak of FMD in 2001 DEFRA has gone further and further 'down the road of biosecurity and hygiene' instead of opting for a different approach focusing on 'animal health and welfare'. It is basically: 'health vs hygiene'. In the case of foot and mouth in 2001 stricter biosecurity measures together with mass slaughter seem to have brought the outbreak under control. In the case of poultry, there is a paradox, insofar as the some recent outbreaks occurred in 'biosecure' indoor units, despite the fact that outdoor units were regarded as yielding the major risks. This risk reversal made some participants reflect further on issues of health and hygiene.

One organic poultry farmer told us that commercial farms have to invest a lot in hygiene and biosecurity because in general they carry in more disease (see \#14). The stocking densities are also higher which means that the birds get more stressed. On free range or organic farms by contrast 'good stockmanship' is balanced against hygiene. Birds are 'more relaxed' and therefore 'seem to have a better immune system', reminiscent of the folklore that a little bit of dirt does you good:

you know we're for sensible levels of hygiene but not the, not sterilising. And I don't think hygiene is the word, hygiene suggests you know actually trying to minimise pathogens so you know these ridiculous adverts where you're encouraged to sort of get rid of every single germ on your toilet. Then they've shown that you have thousands times more germs on your tea towel and other things like that but you know . . . healthy thank god there are a few germs there [...] you know we are living increasingly sterile lives so for us hygiene is a slightly badly word. We're not saying dirt as such, I suppose we're saying you know normal exposure to dirt. We're not meaning carelessness (\#10). 
This participant stresses that not all bacteria and not all exposure to bacteria is bad, that in fact we need 'a regular injecting of normal levels of bacteria'. We need to 'understand [that] bacteria can be good' (see Nerlich and Koteyko, in press). Free range and organic poultry farmers seem to want not only a reversal of risk perception regarding disease transmission, but also a reversal of perception of bacteria, from 'all bacteria are bad' to 'some bacteria are good'. Moreover, a large farmer of laying hens agreed that too much hygiene is counterproductive - and again this assessment also implies blaming 'the other' faction in the tribe:

Yes and just general disinfectant, it's general cleanliness. It's probably the same as they've got in the hospitals, it's a lot of common sense.

[...] as I said before I blame a lot of it on like they keep turkeys in these huge sheds in sterile conditions. I think if those turkeys were running around in the field, A. they'd taste a lot better and B they'd have their own, build up their own immunity to all sorts of disease. I mean I don't know enough about this H5N1 to know whether they would build up an immunity to it but I think most diseases in chickens immunity can be built up to. (\#2)

Increasing the health of the birds by keeping stock density down, reducing stress and generally building up immunity are issues that are considered in government policies on poultry farming, with research commissioned by DEFRA indicating better health and faster weight gain at lower stocking densities (DEFRA, 2003). However, in terms of disease prevention, DEFRA's (2005: 3) definition of biosecurity, as we have seen above, still puts the stress on 'good hygiene practices' rather than health. Cleanliness and hygiene seem to be the two 'magic' formulae which are almost ritualistically invoked by policy makers and industry leaders. This 'magic power' is however questioned by some free range and 
organic farmers, who allude instead to an equally mysterious immune system which strengthens with outdoor living.

Reverting to our overarching tribal metaphor, one could say that policy makers and members of the industry involved in factory-style indoor farming industry leaders worship the god of hygiene and stringent control over thresholds in the hope of warding of the evil of disease, whereas the 'small people' or 'free range people' worship the god of 'health' and subscribe instead to the notion that microbes may be beneficial. Thus from the insights we have presented here, it seems that different factions or interest groups within the poultry industry have developed their own microcultures, complexes of meaning and symbols (Cova and Cova, 2002).

\section{Conclusions}

Our analysis of these interviews reveals that applying the tribal perspective to the poultry industry can yield important insights concerning its response to threats such as avian flu. Rather than a body of recalcitrant producers who need to be cajoled and educated by scientific advice and government policy in order to take precautions, their actions are aligned with their own complex theorisations of risk and their involvement in coordinated social practices reminiscent of ritual. Within the poultry tribe, there are important and complex subdivisions concerning claims about what best to do to protect flocks. The divisions reflect lines of cleavage in the structure of the industry, with the larger scale factory producers aligned with the rituals of hygiene promoted by the Government and the free range or organic farmers often questioning this reliance upon threshold rituals favouring instead the health promoting effects of low densities and outdoor activity.

These divisions are themselves reminiscent of what Maffesoli (1996) describes as 'postmodern tribes' which 'are inherently unstable, small-scale, 'affectual' and can 
be held together through shared emotion and passion. They exist in and through the 'symbolically and ritually manifested commitment of their members'. The hygiene activities described above by those in the industry are reminiscent of 'the (re)construction or (re)possession of meanings through shared experiences and their enactment through rituals' which is 'the most potent form of maintaining tribal identity' (Cova and Cova 2002: 598). Ritual, says Bell (1992), is a means of mediating between thought and action. It is a culturally strategic way of acting. In our case, it reflects ways of mediating risk, and, in alignment with Douglas (1992), a means of managing potential blame.

The tribal affiliations need not be fixed. Within the overarching membership of the poultry tribe, a person can move between the different factions, from factory farmer to free range entrepreneur in the case of one of our informants. This reinforces Maffesoli's insistence on the importance of 'affectual bonds' rather than kinship networks as a basis for membership of the tribe. As in Malinowski's (1922) formulation, it is matters of consensus on the imponderabilia of everyday life, and matters relating to the interpretation of the corpus inscriptorium of advice and guidelines that form the unifying preoccupations of the tribe in question.

To be most effective, campaigns by policy makers to increase awareness about 'biosecurity', and protection against animal diseases, have to be formulated with an awareness of these divisions, especially in a situation where, as DEFRA (2006c) notes, a clear understanding of the poultry industry, its networks and movements, is still absent. A more nuanced understanding of the industry, not only in structural or economic terms but with greater ethnographic sensitivity to its psychosocial topography of tribal affiliations, and the meaning of its rituals in reducing uncertainty and managing threat, might allow policy makers to target 'biosecurity' and 'hygiene' campaigns more effectively. For communication to be 
optimal it must enable people on the ground feel they are being spoken to appropriately, so that they will not be tempted to regard government leaflets as mere 'chicken feed', that is of little value to their 'way of life'.

\section{Acknowledgements}

We want to thank Dr Nick Wright who collected the interviews for this study. The authors gratefully acknowledge the generous support of the ESRC for a grant enabling a study of public discourses about MRSA and Avian Flu: 'Talking cleanliness in health and agriculture' (RES000231306).

\section{References}

ABBATE, R., DI GIUSEPPE, G., MARINELLI, P., ANGELILLO, I.F. (2006).

Knowledge, attitudes, and practices of avian influenza, poultry workers, Italy. Emerging Infectious Diseases 12: pp. 1762-1765.

BARRY, J. (2004) The great influenza: The epic story of the deadliest plague in history (New York, NY, Viking Books). BAUMAN, Z. (1992) Soil, Blood and Identity, Sociological Review 40(4): pp. 675-701.

BELL, C. (192) Ritual Theory, Ritual Practice (Oxford, Oxford University Press).

BRYMAN, A. (2004) Social research methods ( $2^{\text {nd }}$ edition) (Oxford, Oxford University Press).

BRYMAN, A. (2006) Mixed methods (London, Sage Publications Inc.). COVA, B. \& COVA, V. (2002) Tribal marketing: The tribalisation of society and its impact on the conduct of marketing European Journal of Marketing, 36 (5/6), pp. 596-620.

Cauthen, A. N., Swayne, D. E., Schultz-Cherry, S., Perdue, M. L. and Suarez, D. L. (2000). Continued Circulation in China of Highly Pathogenic Avian Influenza Viruses Encoding the Hemagglutinin Gene Associated with the 1997 H5N1 
Outbreak in Poultry and Humans. Journal of Virology, 74(14), pp. 6592-6599,

CYRANOSKI, D. (2001) Outbreak of chicken flu rattles Hong Kong, Nature, 412, pp. 261.

DEFRA (2003) Stocking density and welfare in broilers: Final project report (London Department for Environment, Food and Rural Affairs).

DEFRA (2005) Biosecurity and preventing disease (London, Department for Environment, Food and Rural Affairs.

DEFRA (2006a) Avian influenza: Separating domestic birds from wild birds (London, Department for Environment, Food and Rural Affairs).

DEFRA (2006b) DEFRA's framework response plan for exotic animal diseases (London, Department for Environment, Food and Rural Affairs).

DEFRA (2006c) Network simulations of disease transmission within the poultry industry in Great Britain

http://randd.defra.gov.uk/Default.aspx?Menu=Menu\&Module=More\&Location $=$ No ne\&Completed $=0 \&$ ProjectID $=14386($ Accessed 15/3/2008) DONALDSON, L. (2005) Explaining pandemic flu: A report from the Chief Medical Officer (London, Department of Health).

DOUGLAS, M. (1966) Purity and Danger (London, Routledge).

DOUGLAS, M. (1992) Risk and Blame: Essays in Cultural Theory (London, Routledge).

ELBERS, A. R, FABRI, T. H, DE VRIES, T. S., DE WIT, J. J, PIJPERS, A., KOCH, G. (2004). The highly pathogenic avian influenza A (H7N7) virus epidemic in The Netherlands in 2003 - lessons learned from the first five outbreaks. Avian

Diseases 48(3): pp. 691-705.

FLEMING, D. (2005) Influenza pandemics and avian flu, British Medical Journal 331, pp. 1066-1069.

GEERTZ, C. (1973). The Interpretation of Cultures: Selected Essays. (New York: Basic Books). 
JefFerson, T., FOXLEE, R., DEL MAR, C., DOOLEY, L., FERRONI, E., HEWAK, B. PRABHALA, A., NAIR, S. \& RIVETTI, A. (2008) Physical interventions to interrupt or reduce the spread of respiratory viruses: systematic review, British Medical Journal, 2336, pp. 77-80.

LIN, Y.P., SHAW, M., GREGORY, V., CAMERON, K., LIM, W., KLIMOV, A., SUBBARO, K., GUAN, Y., KRAUSS, S., SHORTRIDGE, K., WEBSTER, R., COX, N. \& HAY, A. (2000) Avian-to-human transmission of H9N2 subtype influenza A viruses. Relationship between H9N2 and H5N1 human isolates, Proceedings of the National Academy of Sciences of the United States of America, 97 (17), pp. 9654-8.

MAFFESOLI, M. (1991) The Ethics of Aesthetics Theory, Culture and Society, 8, pp. 7-20.

MAFFESOLI, M. (1996) The Time of the Tribes: The Decline of Individualism in Mass Society (London, Sage).

MALINOWSKI, B. (1922) The Argonauts of the Western Pacific. An Account of Native Enterprise and Adventure in the Archipelagoes of Melanesian New Guinea (London, Routledge \& Kegan Paul).

MORROW, C. (2006) Biosecurity: An essential tool for modern poultry production http://www.thepoultrysite.com/articles/553/biosecurity-an-essentialtool-for-modern-poultry-production (accessed 14/3/2008).

MOSSIALOS, E. and RUDISILL, C. (2008). Letter: Knowledge about Avian Influenza, European Region. Emerging Infectious Diseases 14. Available at: http://www.cdc.gov/eid/content/14/12/1956.htm NERLICH, B. (2004) War on foot and mouth disease in the UK, 2001: Towards a cultural understanding of agriculture Agriculture and Human Values, 21(1), pp. $15-25$.

NERLICH, B. \& HALLIDAY, C. (2007) Avian flu: the creation of expectations in the interplay between science and the media Sociology of Health \& Illness, 29 (1), pp. 46-65. 
NERLICH, B. \& HALLIDAY, C. (in press). Balancing food risks and food benefits: The coverage of probiotics in the UK national press Sociological Research Online.

ROTH, J. (1957) Ritual and magic in the control of contagion American Sociological Review, 22 (3), 310-314.

SENFT, G. (1997) Magical Conversation on the Trobriand Islands Anthropos, 92 (4-6), pp. 369-391.

SANCO, D. G. (2009). Confirmed human cases of avian influenza since 1997 sorted by subtypes [cited 2009 March 2]. Available from http://ec.europa.eu/health/ph_threats/com/Influenza/avian_influenza_human_en .htm

SHERINGHAM, M. (2006) Everyday life: theories and practices from surrealism to the present (Oxford, Oxford University Press).

Subba, T. B, and Som, S. (2005). Between Ethnography and Fiction: Verrier Elwin and the Tribal Question in India. Hyderabad: Orient Blackswan TUMPEY, T. M, SUAREZ, D. L., PERKINS, L.E, SENNE, D. A, LEE, J. G, LEE, Y.J, MO, I. P, SUNG, H. W, SWAYNE, D. E. (2002). Characterization of a highly pathogenic H5N1 avian influenza A virus isolated from duck meat. Journal of Virology, 76(12), pp. 6344-6355.

TURNER, V. (1995) The ritual process: Structure and anti structure, (New York, NY, Aldine Transaction) WORLD HEALTH ORGANIZATION (2006) WHO strategic action plan for pandemic influenza 2006-2007 (Geneva, World Health Organization) (http://www.who.int/csr/resources/publications/influenza/WHO CDS EPR GIP 2 006 2/en/index.html (accessed 17/08/2007). WORLD HEALTH ORGANIZATION (2008) Cumulative Number of Confirmed Human Cases of Avian Influenza A/(H5N1) Reported to WHO 
http://www.who.int/csr/disease/avian influenza/country/cases table 2008030 5/en/index.html (accessed 10/3/2008).

ZUESSE, E.M. (1974) Taboo and the divine order, Journal of the American Academy of Religion, 42 (3), pp. 482-504. 


\begin{tabular}{|c|c|}
\hline Interview code & Interviewee \\
\hline$\# 1$ & Free-range laying hens, Norfolk \\
\hline$\# 2$ & $\begin{array}{l}\text { Few thousand chickens reared from a few weeks to } \\
\text { sell on. Mostly to owners of small flocks in gardens }\end{array}$ \\
\hline$\# 3$ & $\begin{array}{l}\text { Tens of thousands of laying hens on multiple sites. } \\
\text { Organic; free-range; barn reared }\end{array}$ \\
\hline$\# 4$ & Smallholder with geese, ducks and chickens \\
\hline$\# 5$ & Professor of Food Safety \\
\hline \#6 & Professor of animal production. \\
\hline$\# 7$ & A farmer of 800,000 broiler birds on two sites \\
\hline$\# 8$ & Specialist poultry vet \\
\hline$\# 9$ & $\begin{array}{l}\text { Agricultural Director of an Integrated Poultry } \\
\text { company }\end{array}$ \\
\hline$\# 10$ & Soil Association \\
\hline \#11 & $\begin{array}{l}\text { Agricultural Director of an integrated poultry } \\
\text { company }\end{array}$ \\
\hline \#12 & Nature Reserve Manger \\
\hline \#13 & $\begin{array}{l}\text { A regional manager of Veterinary Laboratories } \\
\text { Association }\end{array}$ \\
\hline \#14 & Poultry manager on an organic farm \\
\hline
\end{tabular}

Table 1 